\title{
Methanocaldococcus indicus sp. nov., a novel hyperthermophilic methanogen isolated from the Central Indian Ridge
}

\author{
Correspondence \\ C. Jeanthon \\ jeanthon@univ-brest.fr
}

\author{
S. L'Haridon, ${ }^{1}$ A.-L. Reysenbach, ${ }^{2}$ A. Banta, ${ }^{2}$ P. Messner, ${ }^{3}$ P. Schumann, ${ }^{4}$ \\ E. Stackebrandt ${ }^{4}$ and C. Jeanthon ${ }^{1}$
}

${ }^{1}$ UMR 6539, Centre National de la Recherche Scientifique, and Université de Bretagne Occidentale, Institut Universitaire Européen de la Mer, F-29280 Plouzané, France

${ }^{2}$ Portland State University, Department of Biology, Portland, OR 97201, USA

${ }^{3}$ Zentrum für Ultrastrukturforschung und Ludwig Boltzmann-Institut für Molekulare Nanotechnologie, Universität für Bodenkultur, A-1180 Wien, Austria

${ }^{4} \mathrm{DSMZ}$ - German Collection of Microorganisms and Cell Cultures, Mascheroder Weg 1b, D-38124 Braunschweig, Germany

\begin{abstract}
An autotrophic, hyperthermophilic methanogen, strain $S L 43^{\top}$, was isolated from a deep-sea hydrothermal chimney sample collected on the Central Indian Ridge at a depth of $2420 \mathrm{~m}$. The coccoid, surface-layer-carrying, Gram-negative-staining cells were heavily flagellated and exhibited a slight tumbling motility. The temperature range for growth at $\mathrm{pH} 6.5$ was $50-86^{\circ} \mathrm{C}$, with optimum growth at $85^{\circ} \mathrm{C}$. The optimum $\mathrm{pH}$ for growth was 6.6 and the optimum $\mathrm{NaCl}$ concentration for growth was $30 \mathrm{~g} \mathrm{I}^{-1}$. The novel isolate used $\mathrm{H}_{2}$ and $\mathrm{CO}_{2}$ as the only substrates for growth and produced methane. Selenium and yeast extract stimulated growth significantly. In the presence of $\mathrm{CO}_{2}$ and $\mathrm{H}_{2}$, the organism reduced elemental sulfur to hydrogen sulfide. Growth was inhibited by chloramphenicol and rifampicin, but not by ampicillin, kanamycin, penicillin or streptomycin. The $\mathrm{G}+\mathrm{C}$ content of the genomic DNA was $30 \cdot 7 \mathrm{~mol} \%$. On the basis of $16 \mathrm{~S}$ rRNA gene sequence analysis, this organism was most closely related to Methanocaldococcus infernus $\mathrm{ME}^{\top}(3 \cdot 2 \%$ distance). Its phylogenetic distinctiveness was confirmed by RFLP analysis of the $16 \mathrm{~S}$ rDNA, a reliable tool for differentiating hyperthermophilic methanococci. On the basis of phylogenetic and physiological characteristics, it is proposed that strain SL43 ${ }^{\top}\left(=\mathrm{DSM} 15027^{\top}=\mathrm{JCM} 11886^{\top}\right.$ ) be designated as the type strain of a novel species, Methanocaldococcus indicus sp. nov.
\end{abstract}

On the basis of differences in 16S rRNA gene sequences and the diversity of temperature growth ranges, the strictly anaerobic, methane-producing members of the order Methanococcales have recently been separated into two families, the mesophilic and thermophilic members of the Methanococcaceae (optimal temperature $\leqslant 70{ }^{\circ} \mathrm{C}$ ) and the hyperthermophilic members of the Methanocaldococcaceae (Whitman et al., 2001). The family Methanocaldococcaceae includes two new genera, Methanocaldococcus and Methanotorris (Whitman \& Jeanthon, 2002). Members of these genera possess less than $93 \% 16 \mathrm{~S}$ rRNA gene sequence similarity and have been exclusively isolated from deep-sea hydrothermal vents. Within the genus Methanocaldococcus, the $16 \mathrm{~S}$ rRNA sequence similarity between species is greater than $95 \%$.

Published online ahead of print on 16 May 2003 as DOI 10.1099/ ijs.0.02700-0.

The GenBank accession number for the $16 \mathrm{~S}$ rDNA sequence of Methanocaldococcus indicus SL43 ${ }^{\top}$ is AF547621.
To date, Methanocaldococcus species have been isolated from actively venting sulfide deposits at deep-sea hydrothermal vents at the East Pacific Rise $\left(13^{\circ} \mathrm{N}\right.$ and $\left.21^{\circ} \mathrm{N}\right)$ (Jones et al., 1983; Jeanthon et al., 1999a) and the Mid-Atlantic Ridge $\left(14^{\circ} 45^{\prime} \mathrm{N}\right.$ and $23^{\circ} \mathrm{N}$ ) (Jeanthon et al., 1998, 1999b) and from hydrothermally heated sediments from Guaymas Basin in the Gulf of California (Zhao et al., 1988; Jones et al., 1989; Jeanthon et al., 1999b).

Because of the paucity of readily identifiable phenotypic characteristics, taxonomic distinction between Methanocaldococcus species on this basis is difficult. Reliable comparison of strains can be made by RFLP analysis of the 16S rDNA (Jeanthon et al., 1999b). This method was used to reveal a novel species isolated from sulfide deposits of a deep-sea hydrothermal vent on the Central Indian Ridge. In this paper, we describe the isolation and characterization of this novel organism.

The novel strain was isolated from chimney samples 
collected in April 2001 at the Kairei vent field on the Central Indian Ridge $\left(25^{\circ} 19^{\prime} \mathrm{S}, 70^{\circ} 02^{\prime} \mathrm{E}\right.$ ) at a depth of $2420 \mathrm{~m}$ (Van Dover et al., 2001). Using the hydraulic arm of the remotely operated vehicle Jason, the chimney samples were placed in insulated containers for the trip to the surface. Once on board, samples were ground anaerobically and stored in serum vials at $4{ }^{\circ} \mathrm{C}$ with $\mathrm{N}_{2}$ in the headspace.

Initial enrichments were done on-board ship in $\mathrm{MSH}$ medium (Boone et al., 1989; http://methanogens.pdx.edu/ OCM_media.html). Seven chimney samples were ground under a stream of $\mathrm{N}_{2}$. Chimney samples were hard and contained pyrite, pyrrhotite, some chalcopyrite, anhydrite and iron oxides. Each sulfide slurry $(0.5 \mathrm{ml})$ was inoculated into $5 \mathrm{ml} \mathrm{MSH}$ medium and the serum tubes were incubated at $80^{\circ} \mathrm{C}$ for $2-3$ days or until turbidity was noted. When growth occurred, it consisted of motile coccoid cells that fluoresced intense green at $420 \mathrm{~nm}$. Positive enrichments were transferred in a culture medium that contained the following $\left(\mathrm{l}^{-1}\right.$ distilled water): $30 \mathrm{~g} \mathrm{NaCl}$, $3 \mathrm{~g} \mathrm{MgCl}_{2} .2 \mathrm{H}_{2} \mathrm{O}, 4 \mathrm{~g} \mathrm{Na}_{2} \mathrm{SO}_{4}, 0.5 \mathrm{~g} \mathrm{KCl}, 0.25 \mathrm{~g} \mathrm{NH}_{4} \mathrm{Cl}$, $0.2 \mathrm{~g} \mathrm{KH}_{2} \mathrm{PO}_{4}, 3.46 \mathrm{~g}$ PIPES, $0.15 \mathrm{~g} \mathrm{CaCl}_{2} .2 \mathrm{H}_{2} \mathrm{O}, 0.5 \mathrm{~g}$ Difco yeast extract, $1 \mathrm{ml}$ trace-element mixture (Widdel \& Bak, 1992), $0.2 \mathrm{mg}$ sodium tungstate, $50 \mu \mathrm{g}$ sodium selenate, $1 \mathrm{ml}$ vitamin mixture (Widdel \& Bak, 1992), $1 \mathrm{ml}$ thiamin solution (Widdel \& Bak, 1992), 0.05 mg vitamin $\mathrm{B}_{12}, 1 \mathrm{ml}$ growth-stimulating factors (Pfennig et al., 1981) and $1 \mathrm{mg}$ resazurin. Prior to autoclaving, the $\mathrm{pH}$ of the medium was adjusted to 6.5 using $5 \mathrm{M} \mathrm{HCl}$. After autoclaving, the $\mathrm{pH}$ of the medium was readjusted to $6 \cdot 5$ at room temperature. $\mathrm{H}_{2} / \mathrm{CO}_{2}(80: 20 ; 200 \mathrm{kPa})$ was used as the gas phase. Pure cultures were obtained and purified on the same medium solidified with $0.7 \%(\mathrm{w} / \mathrm{v})$ Phytagel (Sigma) and reduced with a titanium(III) citrate solution (Zehnder \& Wuhrmann, 1976).

Pure cultures were obtained by streaking subcultures onto solidified culture medium. Pale-yellow, round colonies ( $1 \mathrm{~mm}$ in diameter) were visible on plates after 3 days at $80{ }^{\circ} \mathrm{C}$ in anaerobic jars under a $\mathrm{H}_{2} / \mathrm{CO}_{2}$ atmosphere $(80: 20$; $300 \mathrm{kPa}$ ). Seven colonies were randomly picked and subcultured. Analysis of the RFLP profiles of the 16S rRNA genes showed that all the patterns were identical and were distinct from those of the described species of the genera Methanothermococcus, Methanocaldococcus and Methanotorris (Jeanthon et al., 1999b). One of the pure cultures, designated isolate SL43 ${ }^{\mathrm{T}}$, was selected for further characterization. Stock cultures of isolate SL $43^{\mathrm{T}}$ were stored in culture medium at $4{ }^{\circ} \mathrm{C}$. For long-term storage, pure cultures were stored at $-80^{\circ} \mathrm{C}$ in the same medium containing $10 \%(\mathrm{w} / \mathrm{v})$ DMSO.

Cells of strain SL $43^{\mathrm{T}}$ were irregular cocci, about $1-3 \mu \mathrm{m}$ in diameter depending on the growth phase (Fig. 1). The cells stained Gram-negative (Murray et al., 1994), occurred singly or in pairs and exhibited tumbling motility. As reported for Methanococcales (Whitman \& Jeanthon, 2002), cells from the mid-exponential to late-exponential growth phase lysed rapidly in SDS $(0.01 \%)$ and in distilled water (Boone

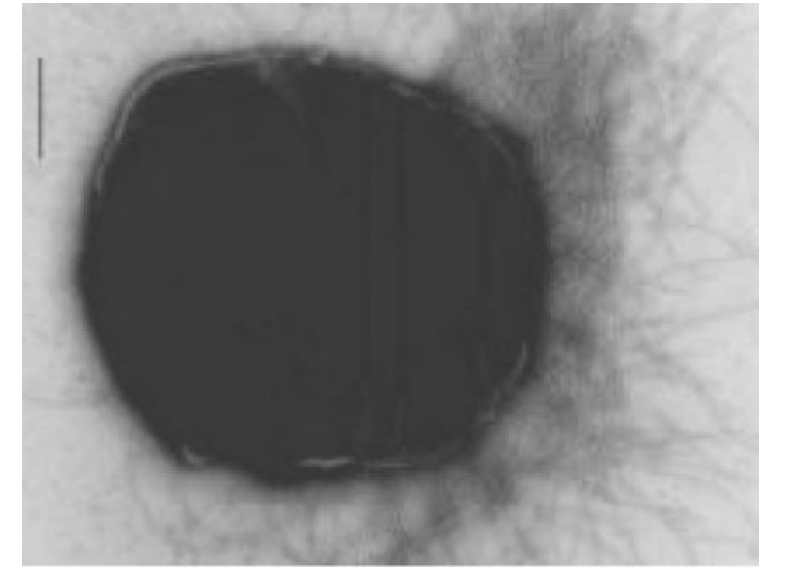

Fig. 1. Electron micrograph of strain $S L 43^{\top}$. Negative staining of a whole cell, showing the flagellation. Bar, $500 \mathrm{~nm}$.

\& Whitman, 1988). Ultrathin sections of cells, prepared as described previously (Sleytr et al., 1988), revealed a delicate, hexagonal S-layer with a lattice constant of approximately $13 \cdot 1 \mathrm{~nm}$. The S-layer could not be recognized clearly all over the cell surface, in particular, in areas of heavy flagellation. Negative staining revealed that flagellation was mainly restricted to one specific region of the cell body, where numerous flagella originated (Fig. 1).

Unless otherwise stated, growth experiments were performed in duplicate in the culture medium. Growth was monitored by measuring the increase in $\mathrm{OD}_{600}$ with a Spectronic 401 spectrophotometer (Bioblock). The $\mathrm{pH}$ range for growth was determined by adding increasing volumes of sterile solutions of $10 \%$ (w/v) $\mathrm{NaHCO}_{3}$ or $8 \%$ (w/v) $\mathrm{Na}_{2} \mathrm{CO}_{3}$ to media buffered with $20 \mathrm{mM}$ PIPES (for $\mathrm{pH} \geqslant 6.5$ ) and $20 \mathrm{mM}$ MES (for $\mathrm{pH} \leqslant 6$ ). Since they may vary with incubation temperature, the $\mathrm{pH}$ values of these media were checked at room temperature after overnight incubation of uninoculated tubes under $\mathrm{H}_{2} / \mathrm{CO}_{2}$ at $85^{\circ} \mathrm{C}$.

Final $\mathrm{OD}_{600}$ values of cultures after $6-8 \mathrm{~h}$ incubation were used to determine the growth ranges and optima for temperature, $\mathrm{pH}$ and $\mathrm{NaCl}$ concentration for strain $\mathrm{SL} 43^{\mathrm{T}}$. The effects of $\mathrm{pH}$ and $\mathrm{NaCl}$ concentration were determined at the optimal temperature for growth. Under these conditions, strain SL43 $3^{\mathrm{T}}$ grew between 50 and $86{ }^{\circ} \mathrm{C}$, with optimum growth at around $85^{\circ} \mathrm{C}$; no growth was detected at 45 or $88^{\circ} \mathrm{C}$. Growth was observed between pH 5.5 and $6 \cdot 7$, with optimum growth at around $\mathrm{pH} 6 \cdot 5$. No growth was observed at $\mathrm{pH} 5 \cdot 2$ or 7 . Growth occurred in $\mathrm{NaCl}$ concentrations ranging from 15 to $50 \mathrm{~g} \mathrm{l}^{-1}$, with optimum growth at $30 \mathrm{~g} \mathrm{l}^{-1}$. No growth was observed at 10 or $60 \mathrm{~g}$ $\mathrm{NaCl} l^{-1}$. Under the optimal conditions for growth, the doubling time of the novel organism was 25-30 min.

Strain SL43 ${ }^{\mathrm{T}}$ is a strictly anaerobic, autotrophic organism. Growth was prevented in the presence of low levels of oxygen, and $\mathrm{H}_{2}$ and $\mathrm{CO}_{2}$ served as the only substrates for 
growth. No growth was observed on acetate $\left(2 \mathrm{~g} \mathrm{l}^{-1}\right)$, formate $\left(5 \mathrm{~g} \mathrm{l}^{-1}\right)$, methanol $(0 \cdot 5 \%, \mathrm{v} / \mathrm{v})$, monomethylamine $\left(2 \mathrm{~g} \mathrm{l}^{-1}\right)$ or yeast extract $\left(2 \mathrm{~g} \mathrm{l}^{-1}\right)$ with a $\mathrm{N}_{2} / \mathrm{CO}_{2}$ $(80: 20 ; 200 \mathrm{kPa})$ or $\mathrm{H}_{2}(100 \% ; 200 \mathrm{kPa})$ headspace. In the presence of $\mathrm{H}_{2}$ and $\mathrm{CO}_{2}$, methane production paralleled growth (Jeanthon et al., 1998). Ammonium $(10 \mathrm{mM})$ was the preferred nitrogen source, but significant growth also occurred in the presence of yeast extract, tryptone, urea, glutamate (all at $2 \mathrm{~g} \mathrm{l}^{-1}$ ) and nitrate $(10 \mathrm{mM})$. When supplemented individually, selenate, tungstate and yeast extract stimulated the growth rate. When sulfur $\left(5 \mathrm{~g} \mathrm{l}^{-1}\right)$ was added to the sulfate-free medium in the presence of $\mathrm{CO}_{2}$ and $\mathrm{H}_{2}$, growth occurred and $\mathrm{H}_{2} \mathrm{~S}$ was produced. No dissimilatory reduction of cystine $\left(5 \mathrm{~g} \mathrm{l}^{-1}\right)$, sulfate or thiosulfate (at $20 \mathrm{mM}$ ) was observed.

Sensitivity to antibiotics supplemented at $25,50,75,100$ and $200 \mu \mathrm{g} \mathrm{ml}^{-1}$ was tested in the culture medium at $80^{\circ} \mathrm{C}$. Strain SL43 ${ }^{\mathrm{T}}$ was resistant to ampicillin, penicillin, streptomycin and kanamycin $\left(200 \mu \mathrm{g} \mathrm{ml}^{-1}\right)$ and was sensitive to chloramphenicol $\left(75 \mu \mathrm{g} \mathrm{ml}^{-1}\right)$ and rifampicin $\left(25 \mu \mathrm{g} \mathrm{ml}^{-1}\right)$.

DNA was isolated after disruption of cells using a French pressure cell (Thermo Spectronic) and purified by hydroxyapatite chromatography (Cashion et al., 1977). The DNA was hydrolysed with P1 nuclease and the nucleotides were dephosphorylated with bovine alkaline phosphatase (Mesbah et al., 1989). The G+C content of the DNA of strain SL43 ${ }^{\mathrm{T}}$ was $30 \cdot 7 \mathrm{~mol} \%$, as determined by the HPLC method (Tamaoka \& Komagata, 1994), and is in the range reported for other members of the genus Methanocaldococcus (Whitman et al., 2001).

A total of 1409 nucleotides of the 16S rRNA gene were sequenced as described previously (Götz et al., 2002). Distance and maximum-likelihood trees (De Soete, 1983; Olsen et al., 1994) (1354 nucleotides were used) placed strain $\mathrm{SL}^{\mathrm{T}} 3^{\mathrm{T}}$ as a relative of Methanocaldococcus infernus $\operatorname{ME}^{\mathrm{T}}(3 \cdot 2 \%$ distance), Methanocaldococcus jannaschii $\mathrm{JAL}^{\mathrm{T}}{ }^{\mathrm{T}}\left(4 \cdot 1 \%\right.$ distance), Methanocaldococcus vulcanius $\mathrm{M}^{\mathrm{T}}$ and Methanocaldococcus fervens $\mathrm{AG}^{\mathrm{T}}{ }^{\mathrm{T}}$ (5.3\% distance)

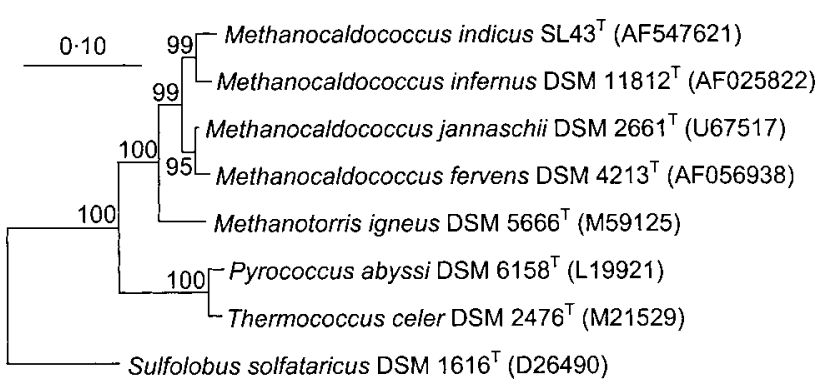

Fig. 2. Phylogenetic relationship of strain $S L 43^{T}$ and other members of the Methanocaldococcaceae revealed by maximumlikelihood analysis. The sequence of the $S L 43^{\top}$ small subunit was aligned with other 16S rRNA gene sequences from the Ribosomal Database Project (Maidak et al., 2001) and GenBank (Benson et al., 2002). The scale bar represents the expected number of changes per sequence position. Numbers at branch nodes are bootstrap values based on 100 bootstrap resamplings.

(Fig. 2). However, the level of $16 \mathrm{~S}$ rDNA sequence similarity between strain SL43 ${ }^{\mathrm{T}}$ and these organisms is lower than the limit $(97 \%)$ used to define distinct species at the DNA level without the requirement for DNA-DNA reassociation tests (Stackebrandt \& Goebel, 1994). This significant phylogenetic distinctiveness was confirmed by RFLP analysis of the 16S rDNA (Jeanthon et al., 1999b), a reliable and useful method for distinguishing species of Methanocaldococcus from each other (Whitman et al., 2001).

Although the novel isolate shared a number of phenotypic features with its relatives, obvious differences exist (Table 1). Strain SL43 ${ }^{\mathrm{T}}$ is distinct from other Methanocaldococcus species, and particularly from Methanocaldococcus infernus, its closest phylogenetic relative, in its maximum $\mathrm{pH}$ and temperature for growth and in the numbers of regions of insertion of flagella into the cell body. This distinctiveness was confirmed by comparing whole-cell protein patterns of strain $\mathrm{SL} 43^{\mathrm{T}}$ with those of type strains of described

Table 1. Differentiating characteristics of Methanocaldococcus species

Taxa: 1, strain SL43 ${ }^{\mathrm{T}}$; 2, Methanocaldococcus infernus; 3, Methanocaldococcus jannaschii; 4, Methanocaldococcus vulcanius; 5, Methanocaldococcus fervens. Data were obtained from Jones et al. (1983), Zhao et al. (1988) and Jeanthon et al. (1998, 1999a). ND, Not determined.

\begin{tabular}{|c|c|c|c|c|c|}
\hline Characteristic & 1 & 2 & 3 & 4 & 5 \\
\hline Range & $50-86$ & $55-91$ & $50-91$ & $49-89$ & $48-92$ \\
\hline $\mathrm{pH}$ range for growth & $5 \cdot 5-6 \cdot 7$ & $5 \cdot 25-7 \cdot 0$ & $5 \cdot 2-7 \cdot 0$ & $5 \cdot 25-7 \cdot 0$ & $5 \cdot 5-7 \cdot 6$ \\
\hline Flagellation apparatus & One extended insertion site & Three tufts of flagella & Two bundles of flagella & Three tufts of flagella & ND \\
\hline Resistance to rifampicin* & - & - & - & - & + \\
\hline
\end{tabular}

${ }^{\star}$ Concentration tested was $50 \mu \mathrm{g} \mathrm{ml}{ }^{-1} ;+$, resistant; - , sensitive. 


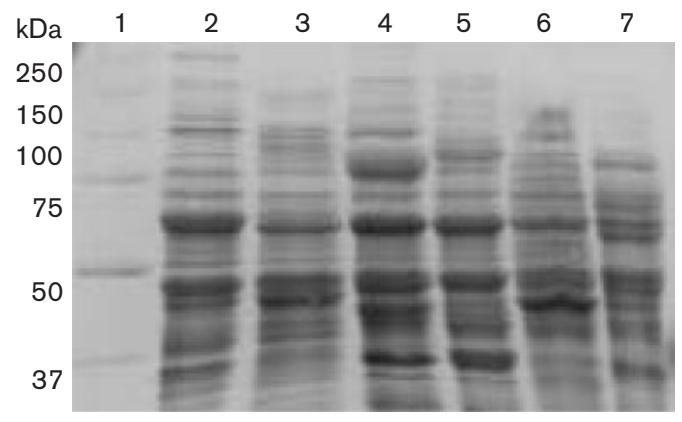

Fig. 3. Electrophoretic analysis of whole-cell proteins of strain SL43 ${ }^{\top}$ (lane 2), Methanocaldococcus infernus $\mathrm{ME}^{\top}$ (3), Methanocaldococcus jannaschii JAL-1 ${ }^{\top}$ (4), Methanocaldococcus fervens $\mathrm{AG} 6^{\top}$ (5), Methanocaldococcus vulcanius $\mathrm{M7}^{\top}$ (6) and Methanocaldococcus igneus $\mathrm{Kol}^{\top}$ (7). Precision protein standards (Bio-Rad) were used as size markers (lane 1). Electrophoretic analysis of whole-cell proteins was performed as described by Keswani et al. (1996).

Methanocaldococcus and Methanotorris species (Fig. 3). We propose that strain $S L 43^{\mathrm{T}}$ represents a novel Methanocaldococcus species, named Methanocaldococcus indicus sp. nov.

\section{Description of Methanocaldococcus indicus sp. nov.}

Methanocaldococcus indicus (in'di.cus. L. masc. adj. indicus of India, referring to the Indian Ocean, where the type strain was isolated).

Cells exhibit a tumbling motility by means of numerous flagella, predominantly inserted at one specific region of the cell body. They are cocci (1-3 $\mu \mathrm{m}$ in diameter), covered with a hexagonal S-layer lattice, and occur singly and in pairs. Cells lyse rapidly in SDS $(0.01 \%)$ and in distilled water. Pale-yellow, round colonies about $1 \mathrm{~mm}$ in diameter form on Phytagel plates. Growth occurs at between 50 and $86^{\circ} \mathrm{C}$, with an optimum at $85^{\circ} \mathrm{C}$, between pH 5.5 and 6.7 , with the optimum at around $\mathrm{pH} 6 \cdot 5$, and between 15 and $50 \mathrm{~g} \mathrm{NaCl} \mathrm{l}^{-1}$, with an optimum of $30 \mathrm{~g} \mathrm{l}^{-1}$. Obligately anaerobic. Chemolithotrophic. Uses $\mathrm{H}_{2}$ and $\mathrm{CO}_{2}$ as energy and carbon sources to produce methane. Growth is stimulated by selenate, tungstate and yeast extract. Sulfur is reduced to $\mathrm{H}_{2} \mathrm{~S}$ in the presence of $\mathrm{CO}_{2}$ and $\mathrm{H}_{2}$. Growth is inhibited by chloramphenicol $\left(75 \mu \mathrm{g} \mathrm{ml}^{-1}\right)$ and rifampicin $\left(25 \mu \mathrm{g} \mathrm{ml}^{-1}\right)$ but not by streptomycin, penicillin $\mathrm{G}$, kanamycin or ampicillin $\left(200 \mu \mathrm{g} \mathrm{ml}^{-1}\right)$. The DNA G $+\mathrm{C}$ content of the type strain is $30.7 \mathrm{~mol} \%$ (as determined by HPLC). Distinguished from other Methanocaldococcus strains by comparison of whole-cell protein patterns.

The type strain, strain $\operatorname{SL} 43^{\mathrm{T}}\left(=\mathrm{DSM} \quad 15027^{\mathrm{T}}=\mathrm{JCM}\right.$ $11886^{\mathrm{T}}$ ), was obtained from a deep-sea hydrothermal vent chimney in the Kairei vent field on the Central Indian Ridge.

\section{Acknowledgements}

The work performed in Plouzané was supported by a grant from PRIR (Programme de Recherche d'Interêt Régional, Conseil Régional de Bretagne) and INTAS (International Association for the Promotion of Co-operation with Scientists from the New Independent States of the Former Soviet Union) (grant no. 99-1250). The work performed at Portland was supported, in part, by grants NSF-OCE9712358 and NSF-OCE0083134. The work performed in Wien was supported by the Austrian Science Fund (project P15840). We thank Harald Mayer and Andrea Scheberl for excellent technical assistance.

\section{References}

Benson, D. A., Karsch-Mizrachi, I., Lipman, D. J., Ostell, J., Rapp, B. A. \& Wheeler, D. L. (2002). GenBank. Nucleic Acids Res 30, 17-20.

Boone, D. R. \& Whitman, W. B. (1988). Proposal of minimal standards for describing new taxa of methanogenic bacteria. Int J Syst Bacteriol 38, 212-219.

Boone, D. R., Johnson, R. L. \& Lui, Y. (1989). Diffusion of the interspecies electron carriers $\mathrm{H}_{2}$ and formate in methanogenic ecosystems and its implications in the measurement of $K_{\mathrm{m}}$ for $\mathrm{H}_{2}$ or formate uptake. Appl Environ Microbiol 55, 1735-1741.

Cashion, P., Holder-Franklin, M. A., McCully, J. \& Franklin, M. (1977). A rapid method for the base ratio determination of bacterial DNA. Anal Biochem 81, 461-466.

De Soete, G. (1983). A least squares algorithm for fitting additive trees to proximity data. Psychometrika 48, 621-626.

Götz, D., Banta, A., Beveridge, T. J., Rushdi, A. I., Simoneit, B. R. T. \& Reysenbach, A.-L. (2002). Persephonella marina gen. nov., sp. nov. and Persephonella guaymasensis sp. nov., two novel, thermophilic, hydrogen-oxidizing microaerophiles from deep-sea hydrothermal vents. Int J Syst Evol Microbiol 52, 1349-1359.

Jeanthon, C., L'Haridon, S., Reysenbach, A. L., Vernet, M., Messner, P., Sleytr, U. B. \& Prieur, D. (1998). Methanococcus infernus sp. nov., a novel hyperthermophilic lithotrophic methanogen isolated from a deep-sea hydrothermal vent. Int J Syst Bacteriol 48, 913-919.

Jeanthon, C., L'Haridon, S., Reysenbach, A.-L., Corre, E., Vernet, M., Messner, P., Sleytr, U. B. \& Prieur, D. (1999a). Methanococcus vulcanius sp. nov., a novel hyperthermophilic methanogen isolated from East Pacific Rise, and identification of Methanococcus sp. DSM $4213^{\mathrm{T}}$ as Methanococcus fervens sp. nov. Int J Syst Bacteriol 49, 583-589.

Jeanthon, C., L'Haridon, S., Pradel, N. \& Prieur, D. (1999b). Rapid identification of hyperthermophilic methanococci isolated from deep-sea hydrothermal vents. Int J Syst Bacteriol 49, 591-594.

Jones, W. J., Leigh, J. A., Mayer, F., Woese, C. R. \& Wolfe, R. S. (1983). Methanococcus jannaschii sp. nov., an extremely thermophilic methanogen from a submarine hydrothermal vent. Arch Microbiol 136, 254-261.

Jones, W. J., Stugard, C. E. \& Jannasch, H. W. (1989). Comparison of thermophilic methanogens from submarine hydrothermal vents. Arch Microbiol 151, 314-318.

Keswani, J., Orkand, S., Premachandran, U., Mandelco, L., Franklin, M. J. \& Whitman, W. B. (1996). Phylogeny and taxonomy of mesophilic Methanococcus spp. and comparison of rRNA, DNA hybridization, and phenotypic methods. Int J Syst Bacteriol 46, 727-735.

Maidak, B. L., Cole, J. R., Lilburn, T. G. \& 7 other authors (2001). The RDP-II (Ribosomal Database Project). Nucleic Acids Res 29, 173-174. 
Mesbah, M., Premachandran, U. \& Whitman, W. B. (1989). Precise measurement of the $\mathrm{G}+\mathrm{C}$ content of deoxyribonucleic acid by highperformance liquid chromatography. Int J Syst Bacteriol 39, 159-167.

Murray, R. G. E., Doetsch, R. N. \& Robinow, C. F. (1994) Determinative and cytological light microscopy. In Methods for General and Molecular Bacteriology, pp. 21-41. Edited by P. Gerhardt, R. G. E. Murray, W. A. Wood \& N. R. Krieg. Washington, DC: American Society for Microbiology.

Olsen, G. J., Matsuda, H., Hagström, R. \& Overbeek, R. (1994). fastDNAmL: a tool for construction of phylogenetic trees of DNA sequences using maximum likelihood. Comput Appl Biosci 10, 41-48.

Pfennig, N., Widdel, F. \& Trüper, H. G. (1981). The dissimilatory sulfate-reducing bacteria. In The Prokaryotes, 2nd edn, pp. 926-940. Edited by M. Starr, H. Stolp, H. G. Trüper, A. Balows \& H. G. Schlegel. New York: Springer.

Sleytr, U. B., Messner, P. \& Pum, D. (1988). Analysis of crystalline bacterial surface layers by freeze-etching, metal-shadowing, negative staining and ultrathin sectioning. Methods Microbiol 20, 29-60.

Stackebrandt, E. \& Goebel, B. M. (1994). Taxonomic note: a place for DNA-DNA reassociation and $16 \mathrm{~S}$ rRNA sequence analysis in the present species definition in bacteriology. Int J Syst Bacteriol 44, 846-849.

Tamaoka, J. \& Komagata, K. (1994). Determination of DNA base composition by reversed-phase high-performance liquid chromatography. FEMS Microbiol Lett 25, 125-128.
Van Dover, C. L., Humphris, S. E., Fornari, D. \& 24 other authors (2001). Biogeography and ecological setting of Indian Ocean hydrothermal vents. Science 294, 818-823.

Whitman, W. B. (2001). Genus I. Methanocaldococcus gen. nov. In Bergey's Manual of Systematic Bacteriology, 2nd edn, vol. 1, pp. 243-245. Edited by D. R. Boone, R. W. Castenholz \& G. M. Garrity. New York: Springer.

Whitman, W. B. \& Jeanthon, C. (2002). The order Methanococcales. In The Prokaryotes, An Electronic Resource for the Microbiological Community. Edited by M. Dworkin. New York: Springer.

Whitman, W. B., Boone, D. R. \& Koga, Y. (2001). Order I. Methanococcales Balch and Wolfe 1981, 216 ${ }^{\mathrm{VP}}$. In Bergey's Manual of Systematic Bacteriology, 2nd edn, vol. 1, p. 236. Edited by D. R. Boone, R. W. Castenholz \& G. M. Garrity. New York: Springer.

Widdel, F. \& Bak, F. (1992). Gram-negative mesophilic sulfatereducing bacteria. In The Prokaryotes, 2nd edn, pp. 3352-3378. Edited by A. Balows, H. G. Trüper, M. Dworkin, W. Harder \& K. H. Schleifer. New York: Springer.

Zehnder, A. J. B. \& Wuhrmann, K. (1976). Titanium(III) citrate as a nontoxic oxidation-reduction buffering system for the culture of obligate anaerobes. Science 194, 1165-1166.

Zhao, H., Wood, A. G., Widdel, F. \& Bryant, M. P. (1988). An extremely thermophilic Methanococcus from a deep-sea hydrothermal vent and its plasmid. Arch Microbiol 150, 178-183. 